\title{
The Effect of Paracetamol and Codeine Analgesic Combination on Creatinine Levels in Male Wistar Rats
}

\author{
Vianney Natasaputra ${ }^{1 *}$, Taufik Eko Nugroho ${ }^{2}$
}

${ }^{1}$ Medical Faculty, Diponegoro University, Indonesia

${ }^{2}$ Teaching Staff, Anaesthesiology Department, Diponegoro University, Indonesia

Keywords:
Codeine
Creatinine Serum
Pain
Paracetamol

*) Correspondence to: vianneyli227@gmail.com

Article history:

Received 18-05-2020

Accepted 3 -06-2020

Availableonline 01-07-2020

\begin{abstract}
Background: Pain is one of the most common complaints in patients. Combination of paracetamol and codeine is an alternative analgesic combination in chronic pain management. They belong to a different group of analgesic and have a different mechanism of action. Combination of these drugs gives a better potential in pain management. However, these drugs also have a potential side effect on the kidney. Objective: This study was conducted to identify the effect of administration of paracetamol and codeine combination toward creatinine serum level on male Wistar rats.

Methods: An experimental study of post-test only control group design. The sample was 20 Wistar rats, randomized into four groups: control group, a group receiving paracetamol $32 \mathrm{mg} / \mathrm{kg}$ body weight, a group receiving codeine $1,9 \mathrm{mg} / \mathrm{kg}$ body weight, and a group receiving paracetamol $32 \mathrm{mg} / \mathrm{kg}$ body weight and codeine 1,9 $\mathrm{mg}$ combination, administered four times a day orally using gastric instillation for 28 days. At the $29^{\text {th }}$ day, blood is collected from retro-orbital vessel to measure the serum creatinine levels. Statistical analysis was conducted using ANOVA Test.

Results: Obtained from statistical analysis, there is no significant difference in serum creatinine levels in Wistar rats given all treatment group $(p>0,05)$.

Conclusion: There is no significant difference in serum creatinine levels between the administration of paracetamol and codeine combination compared to the control group.
\end{abstract}

DIMJ, 2020, 1(1), 5-9 DOI: https://doi.org/10.14710/dimj.v1i1.7833

\section{Introduction}

Pain is defined as an unpleasant sensory and or emotional experience, which is associated with actual or potential tissue damage. This sensation delivered to the brain through sensory neuron fibre. ${ }^{1}$

Until now, pain is one of the most common complaints presented by patients. Approximately 50 million Americans had chronic pain. ${ }^{2}$ In England, it is estimated that 8 million people suffer chronic pain and $13 \%$ of its population have chronic pain varying from moderate to severe pain for more than six months. ${ }^{3}$

Based on the duration, pain can be classified into acute pain and chronic pain. It can also be classified based on the degree of intensity into three groups, which mild pain, moderate pain and severe pain. Acute pain lasts about $1-7$ days, while chronic pain can last until six months or more. ${ }^{4}$

Pain management can be done through pharmacology and non-pharmacology therapy. A non-opioid analgesic such as NSAID and paracetamol or acetaminophen can be used for mild pain. Moderate pain can be treated by non-opioid analgesic as monotherapy or combined with a weak opioid such as hydrocodone and if necessary, adjuvant analgesic can be added. In the case of severe pain, NSAID can be combined with strong opioid and adjuvant analgesic if necessary. ${ }^{4}$ 
Analgesic or painkiller is a substance that in a therapeutic dose, can reduce the pain. Excessive use of analgesic might lead to several side effects, such as digestive tract haemorrhage, hepatotoxicity or increase the risk factor of kidney failure. ${ }^{5}$

Paracetamol or acetaminophen is a non-opioid analgesic that also provide an antipyretic effect. It is widely used in case of mild until moderate pain. ${ }^{6,7}$ Meanwhile, codeine is a weak opioid analgesic that is widely used for treating post-surgery pain, cancer pain and other severe pain. Codeine has several side effects, such as hypotension, respiratory depression, elevated intracranial pressure and gastric obstruction. ${ }^{8,9}$

Excessive use of analgesic can induce kidney damage and increase the risk factor of renal failure. There is a various mechanism of kidney injury based on the drug, such as by causing chronic interstitial inflammation and fibrosis, thickening of the vascular wall in the kidney, renal papilla necrosis, and cortex necrosis. ${ }^{12}$

Serum creatinine is a substance produced by catabolism of muscle keratin phosphate. It can be used as a marker to assess renal function. Creatinine serum level will increase in case of renal toxicity or renal injury. ${ }^{13,14}$

\section{Method}

\subsection{Sample and Treatment}

This study uses an experimental research form with the Post-Test Only Control Group Design approach, which uses 20 male Wistar rats as the object of research. Treatment was given for 28 days. The experimental animals were divided into four groups, namely the control and treatment groups (Table 1) where each group consisted of 6 experimental animals with the following criteria:

a. Inclusion criteria: (1) male Wistar rats, (2) 2-3 months old, (3) healthy and active, (4) weight 200-250 grams, (5) no anatomical abnormalities.

b. Exclusion criteria: Rats die during adaptation and treatment.
Table 1.Distribution of control groups and treatment groups

\begin{tabular}{lc}
\hline Group & \multicolumn{2}{c}{ Treatment } \\
\hline $\mathrm{K}$ & $\begin{array}{c}\text { Group control that are given standard food } \\
\text { and drinks }\end{array}$ \\
\hline P1 & $\begin{array}{c}\text { Male Wistar rats that are given standard } \\
\text { food and drinks }+ \text { Paracetamol dose } 32 \\
\text { mg/kg body weight four times/day for } 28 \\
\text { days }\end{array}$ \\
\hline P2 & $\begin{array}{l}\text { Male Wistar rats that are given standard } \\
\text { food and drinks + codeine dose } 1,9 \mathrm{mg} / \mathrm{kg} \\
\text { body weight four times/day for } 28 \text { days }\end{array}$ \\
\hline P3 & $\begin{array}{l}\text { Male Wistar rats that are given standard } \\
\text { food and drinks }+ \text { combination of } \\
\text { paracetamol with dose } 32 \mathrm{mg} / \mathrm{kg} \text { body } \\
\text { weight and codeine } 1,9 \mathrm{mg} / \mathrm{kg} \text { body } \\
\text { weight four times/day for } 28 \text { days }\end{array}$ \\
\hline
\end{tabular}

The dosage of paracetamol and codeine used has been converted from human doses to rat doses. The dose calculation for paracetamol is $500 \mathrm{mg} \mathrm{x}$ $0,018 \times(50 \mathrm{~kg}: 70 \mathrm{~kg}): 200 \times 1000=32 \mathrm{mg} / \mathrm{kg}$ body weight, the dose of codeine $30 \mathrm{mg} \times 0,018 \mathrm{x}$ $(50 \mathrm{~kg}: 70 \mathrm{~kg}): 200 \times 1000=1,9 \mathrm{mg} / \mathrm{kg}$ body weight, and the combination of paracetamol dose $500 \mathrm{mg} \times 0,018 \times(50 \mathrm{~kg}: 70 \mathrm{~kg}): 200 \times 1000=32$ $\mathrm{mg} / \mathrm{kg}$ body weight and codeine $30 \mathrm{mg} \times 0,018 \times$ $(50 \mathrm{~kg}: 70 \mathrm{~kg}): 200 \times 1000=1,9 \mathrm{mg} / \mathrm{kg}$ body weight.

Before being treated, all Wistar rats were acclimatized first for seven days by being caged and fed the same standard and drink in ad libitum. After that, each group of rats was treated according to the above mentioned for 28 days. On the 29th day, blood samples were taken through Wistar rat retroorbital blood vessels. Creatinine levels were then measured in the Clinical Pathology laboratory.

\subsection{Measurement of Creatinine Level}

Blood samples were taken directly from retroorbital blood vessels, and then creatinine levels were examined by Jaffe examination method without deproteinization. The unit used is $\mathrm{Mg} / \mathrm{dl}$.

\section{Result}

\subsection{Data analysis}

The data obtained were processed by computer programs and analysed by Shapiro-Wilk normality test, Levene homogeneity test, and One Way ANOVA statistical test. 
Table 2. Creatinine levels in the control group and treatment group

\begin{tabular}{ccc}
\hline Groups & Mean & $\begin{array}{c}\text { Standard } \\
\text { Deviation }\end{array}$ \\
\hline Control & 0,3760 & 0,04615 \\
Treatment 1 & 0,3380 & 0,03033 \\
Treatment 2 & 0,3240 & 0,03057 \\
Treatment 3 & 0,3560 & 0,03847 \\
\hline
\end{tabular}

Table 3. Test for normality and homogeneity

\begin{tabular}{ccc}
\hline Groups & Shapiro - Wilk & Levene Statistic \\
\cline { 2 - 3 } & Sig. & Sig. \\
\hline Control & 0,568 & \\
Treatment 1 & 0,086 & \\
Treatment 2 & 0,492 & 0.994 \\
Treatment 3 & 0,083 & \\
\hline
\end{tabular}

Table 4. One Way ANOVA Test

\begin{tabular}{cc}
\hline Groups & P \\
\hline Control & \\
Treatment 1 & $0,195^{*}$ \\
Treatment 2 & \\
Treatment 3 & \\
\hline
\end{tabular}

*Significant is $\mathrm{p}<0.05$

Based on the result of One Way ANOVA Test, it is obtained that the result is not significant.

\section{Discussion}

This study compared differences in serum creatinine levels in the administration of paracetamol and codeine orally. The sample of this study was 20 Wistar rats based on predetermined inclusion criteria. Wistar rats then divided into four groups, namely 5 Wistar rats as a control group, 5 Wistar rats with oral paracetamol administration at a dose of $32 \mathrm{mg} / \mathrm{kg}$ body weight 4 times per day as a treatment group 1, 5 Wistar rats with oral codeine dose $1,9 \mathrm{mg} / \mathrm{kg}$ body weight 4 times per day as treatment group 2 and 5 rats with a combination of oral paracetamol dose of $32 \mathrm{mg} / \mathrm{kg}$ body weight and oral codeine dose of $1,9 \mathrm{mg} / \mathrm{kg}$ body weight 4 times per day as a treatment group 3. Each group was treated for 28 days.

The results of this study found out that there is no significant difference in creatinine levels between treatment group 1, treatment group 2, treatment group 3 and a control group.

In treatment group 1, which is given standard food and drink and paracetamol dose $32 \mathrm{mg} / \mathrm{kg}$ body weight did not give a significant difference in creatinine serum level. Mechanism of renal injury induced by paracetamol is still unclear. One of the hypothesis widely accepted is that paracetamol metabolite, NAPQI, which is produced by oxidation will be reduced by glutathione into mercapturate acid. If there is a high concentration of NAPQI, glutathione concentration will be reduced drastically. This condition will initiate lipid peroxidase which caused cell injury and tubular cells apoptosis. ${ }^{37}$

Several factors make the result insignificant, such as a dosage of the treatment. Based on previous research by Suchismita Roy, administration of paracetamol dose $550 \mathrm{mg} / \mathrm{kg}$ body weight on Wistar rats for 14 days will give nephrotoxic effect in the form of elevated creatinine serum level and degenerative changes on tubular cells in a significant level compared to the control groups which only given standard food and drink. ${ }^{35}$

Another factor is the duration of the treatment. In this research, the researcher only gives the treatment for 28 days. Based on previous research by Cynthia A. Naughton, administration of paracetamol with the dosage of more than 1 gram per day for two years will increase the risk of chronic interstitial nephropathy. ${ }^{36}$

In treatment group 2, which is given standard food and drink and codeine dose $1,9 \mathrm{mg} / \mathrm{kg}$ body weight did not give a significant difference in creatinine serum level. Renal injury is induced by codeine's active metabolite, which is morphine. ${ }^{39}$ Morphine cause degeneration on renal tubular cells by inhibiting glutathione reductase hence free radical will be elevated in cell and leads to cell injury. ${ }^{40}$

Dosage of codeine administration can be a factor that caused the insignificant result. Based on previous research, administration of high dose codeine $(25 \mathrm{mg} / \mathrm{kg}$ body weight $)$ and extreme dose codeine ( $50 \mathrm{mg} / \mathrm{kg}$ body weight) for 28 days results in a significant increase of creatinine serum level of male Wistar rats. ${ }^{38}$

In treatment 3 group, which is given combination of standard food and oral paracetamol dose of $32 \mathrm{mg} / \mathrm{kg}$ bodyweight and oral codeine dose of $1,9 \mathrm{mg} / \mathrm{kg}$ bodyweight for 28 days also did not give a significant difference in creatinine serum level. This result can be affected by the dosage of administration. Until now, no research measured the effect of a combination of paracetamol and codeine on creatinine serum, however there is previous research conducted that shows $500 \mathrm{mg}$ paracetamol mg combined with $30 \mathrm{mg}$ codeine could give effective analgesic effects and insignificant side effect. ${ }^{41}$ Administration of 650 $\mathrm{mg}$ paracetamol and $60 \mathrm{mg}$ codeine increase drug's side effects. ${ }^{42}$

Limitations in this study are that the authors cannot control several factors, including other 
disease factors, as well as intrinsic factors such as resistance and susceptibility of mice. Besides, the lack of research time caused the authors to be unable to vary the duration of drug administration.

\section{Conclusion}

In this study, it can be concluded that administration of a combination of paracetamol with a dose of $32 \mathrm{mg} / \mathrm{kg}$ body weight and codeine dose of $1,9 \mathrm{mg} / \mathrm{kg}$ body weight four times a day for 28 days orally did not cause a significant difference in serum creatinine level.

\section{Ethical Approval}

Ethical clearance was obtained from Research Ethics Commission Medical Faculty Diponegoro University with the number of 38/EC/H/KEPK/FKUNDIP/V/2019.

\section{Conflicts of Interest}

The authors declare no conflict of interest.

\section{Funding}

No specific funding was provided for this article.

\section{Author Contributions}

Writing-original draft preparation, Vinney Natasaputra; writing-review and editing, dr. Taufik Eko Nugroho, M. Si Med, Sp. An

\section{Acknowledgements}

This work was supported by Department of Anesthesiology, Faculty of Medicine, Diponegoro University.

\section{References}

1. Kumar KH, Elavarasi P. Definition of pain and classification of pain disorders. J Adv Clin Res Insights. 2016;3(6):87-90.

2. National Pharmaceutical Council. Section II: Assessment of Pain. Pain Curr Underst Assessment, Manag Treat. 2001;(12):1-94.

3. Fayaz A, Croft P, Langford RM, Donaldson LJ, Jones GT. Prevalence of chronic pain in the UK: a systematic review and metaanalysis of population studies. 2016.

4. Nandar S. Nyeri Secara Umum (General Pain). 2015(6).

5. Samuelsen P-J. Use of analgesics in the general population. 2016;(5):1-70.

6. Twycross R, Pace V, Mihalyo M, Wilcock A. Acetaminophen (Paracetamol). J Pain Symptom Manage. 2013;46(5):747-55.
7. Inflammatory Drugs, Drugs Used To Treat Gout, and Disease-Modifying Antirheumatic Drugs.

8. FDA. Highlitghts of Prescribing Information. Depression. 2015;

9. Moriarty O, McGuire BE, Finn DP, Shirama FH, Miasso AI, Perez-Alvarez S, et al. NIH Public Access. Pain Physician. 2012;11(1):2098-114.

10. Murnion BP. Combination analgesics in adults. Aust Prescr. 2010;33(4):113-5.

11. Abdel C, Bpharm S, Maher CG, Phty B, Mclachlan A, Phd B. Investigating the efficacy and safety of over-the-counter codeine containing combination analgesics for pain and codeine based antitussives. 2016;(3):1-53.

12. Sampathkumar K, Rajiv A, Sampathkumar D. Analgesic Nephropathy--A Painful Progression. Clin Med Insights Urol. 2016;9:CMU.S13179.

13. Jhee J, Hwang S, Song J, Lee S. Upper Normal Serum Creatinine Concentrations as a Predictor for Chronic Kidney Disease: Analysis of 14 Years' Korean Genome and Epidemiology Study (KoGES). J Clin Med. 2018;7(11):463.

14. Salazar JH. Overview of Urea and Creatinine. Lab Med. 2015;45(1):e19-20.

15. Świeboda P, Filip R, Prystupa A, Drozd M. Assessment of pain: types, mechanism and treatment. 2013;(12).

16. Jungquist CR, Vallerand AH, Kwon KN, Polomano RC, Sicoutris C. Assessing and Managing Acute Pain. AJN, Am J Nurs. 2017;117(12):S4-11.

17. Treede RD, Rief W, Barke A, Aziz Q, Bennett MI, Benoliel R, et al. A classification of chronic pain for ICD-11. Pain. 2015;156(6):1003-7.

18. Dewanto G. Patofisiologi Nyeri (Pain). Simp nyeri. 2017;13:11-29.

19. Patel NB. Guide to Pain Management in Low-Resource Settings. 2010;

20. Fricová J. Nonopioid analgesics. Cas Lek Cesk. 2018;157(2):74-8.

21. Trivedi M, Shaikh S, Gwinnutt C. Pharmacology of Opioids - Part 1. Anaesth Tutor Week. 2007;64(8):1-7.

22. Committee BP. Pain Management Guideline. 2017;1-30.

23. WHO. WHO's Cancer Ladder for Adults [Internet][cited 2019 March 7]. Available from:

https://www.who.int/cancer/palliative/painla 
dder/en/

24. Sharma C V, Mehta V. Paracetamol: Mechanisms and updates. Contin Educ Anaesthesia, Crit Care Pain. 2014;14(4):153-8.

25. Moriarty C, Carroll W. Ibuprofen in paediatrics: Pharmacology, prescribing and controversies. Arch Dis Child Educ Pract Ed. 2016;101(6):327-30.

26. Badan POM RI. Safety Alert Informasi Untuk Dokter Kontraindikasi Baru untuk Kodein Terkait dengan Risiko Depresi Pernapasan. Jakarta; 2016.

27. Kim I, Barnes AJ, Oyler JM, Schepers R, Joseph RE, Cone EJ, et al. Plasma and oral fluid pharmacokinetics and pharmacodynamics after oral codeine administration. Clin Chem. 2002;48(9):1486-96.

28. Moore, L Keith. Dalley, F Arthur. Agur RMA. Moore Clinically Oriented Anatomy, 7th Edition. 2014.

29. Yusuf AA. Diktat Kuliah Histologi Sistem Perkemihan. Jakarta: Fakultas Kedokteran Universitas Indonesia; 2001.

30. Hallgrímsson B, Benediktsson H, Vize PD. Anatomy and Histology of the Human Urinary System. Kidney From Norm Dev to Congenit Dis. 2003;149-67.

31. Sherwood L. Fisiologi Manusia : Dari Sel ke Sistem. 6th ed. Jakarta: EGC; 2010.

32. Verdiansah. Pemeriksaan Fungsi Ginjal. J Diabetes [Internet]. 2009;1(2):A64. [cited 2019 March 15] Available from: http://www.embase.com/search/results?suba ction=viewrecord $\&$ from $=$ export $\&$ id $=\mathrm{L} 7021$ 2499\%0Ahttp://dx.doi.org/10.1111/j.1753- 0407.2009.00019.x

33. Mazer MD M, PharmD, Perrone MD J. Acetaminophen-Induced Nephrotoxicity. J Med Toxicol. 2008;4(1):1-5.

34. Mallappallil M, Sabu J, Friedman EA, Salifu M. What do we know about opioids and the kidney? Int J Mol Sci. 2017;18(1).

35. Samanta A, Sinha B, Nandi DK. ans net. J Biol

Sci.2015;15(4):187-93. http://dx.doi.org/10.3923/jbs.2015.187.193

36. Naughton CA. Drug-Induced Nephrotoxicity. 2008;

37. Ozkaya O, Genc G, Bek K, Sullu Y, Ozkaya $\mathrm{O}$, Genc $\mathrm{G}$, et al. A case of acetaminophen (paracetamol) causing renal failure without liver damage in a child and review of literature. 2010;6049.

38. Owoade O, Adetutu A, Olorunnisola O. Codeine-mediated Haematoxicity, Hepatotoxicity and Nephrotoxicity in Male Albino Rats. 2019;(3).

39. Mahda N, Lubis D, Ramadhania ZM, Apoteker PS, Farmasi F, Padjadjaaran U, et al. Farmaka Farmaka. 2015;16:64-70.

40. Singh VP, Singh N, Jaggi AS. A Review on Renal Toxicity Profile of Common Abusive Drugs. 2013;17:347-58.

41. Mattia C. A look inside the association codeine-paracetamol: clinical pharmacology. 2015;507-16.

42. Ho A, Au Y, Choi SW, Cheung CW, Leung YY. The Efficacy and Clinical Safety of Various Analgesic Combinations for PostOperative Pain after Third Molar Surgery : A Systematic Review and Meta-Analysis. 2015;1-25. 